\title{
Development of Preverbal Communication Skills Scale for Children with Multiple Disabilities and Visual Impairment ${ }^{1}$
}

\author{
Emine Ayy1ld1z \\ Nur Akçin ${ }^{3}$ \\ Y1ldı Güven ${ }^{4}$
}

\begin{abstract}
Communication is crucial for any human being and the children with disabilities are no exception. Due to the number and combination of their disabilities and/or conditions, children with multiple disabilities and visual impairment (MDVI) have especially limitations of the ability to communicate the meaningful and functional way with their environment. In order to improve the communication skills of children with MDVI, it is very important to identify unique, individual communication behaviors of these children. Thus, the aim of this study was to develop a valid and reliable developmental assessment tool to evaluate preverbal communication skills of Turkish children with MDVI.

Sequential explanatory mixed methods were used in the study. In the qualitative phase, semistructured interviews were conducted with the mothers of 34 children suffering from MDVI to explore the preverbal communication behaviors of the children based on the daily observances of their mothers' with a descriptive analysis being performed on the data. From the findings of the interviews and the literature review, Preverbal Communication Skills Scale for Children with Multiple Disabilities and Visual Impairment (PCSS-MDVI) and the scoring guide were developed. During the quantitative phase, 65 mothers of children with MDVI were given this scale in order to determine the validity and reliability of the scale. For the reliability analysis, 34 mothers of typically developing (TD) children age between 1 to 24 months old also were given the scale.

The findings of the qualitative phase indicated that children with MDVI were communicating mostly with preverbal behaviors and the analysis on data from the quantitative phase with respect to item analysis, reliability and validity revealed that the scale is valid and reliable. The scale has 17 items and three subscales, which are; regulating behaviors, social interaction and joint attention.

The majority of children with MDVI cannot communicate verbally and there is lack of studies and assessment tools for the purpose of effectively evaluate these children's preverbal communicative behaviors in our country. Based on the analysis, the PCSS-MDVI has been demonstrated good preliminary psychometric properties and it can be used as an instrument to evaluate preverbal communication behaviors of children with MDVI. It is the preliminary study of the development of the scale. Thus, validation of the scale should be repeated with more participants and the data of the video observations of preverbal communication behaviors of

\footnotetext{
1 This study is a summary of the first author's doctoral thesis and it was presented in the V. European Conference on Social and Behavioral Sciences (2014).

${ }^{2}$ Assist. Prof. Dr., Istanbul Medeniyet University, Faculty of Educational Science, Department of Primary Education, Preschool Education Teachers' Training Program, emine.ayyildiz@medeniyet.edu.tr

3 Assoc. Prof. Dr., Marmara University, Ataturk Faculty of Education, Department of Special Education, Mentally Disabled Teacher Education, nakcin@marmara.edu.tr

${ }^{4}$ Prof. Dr., Marmara University, Ataturk Faculty of Education, Department of Primary Education, Preschool Education Teachers' Training Program, yguven@marmara.edu.tr
} 
Ayylldı, E., Akçin, N., \& Güven, Y. (2016). Development of Preverbal Communication Skills Scale for Children with Multiple Disabilities and Visual Impairment. Journal of Human Sciences, 13(2), 2668-2681. doi:10.14687/jhs.v13i2.3718

children with MDVI should be added to the analysis.

Keywords: Preverbal Communication Behaviors; Children With Multiple Disabilities and Visual Impairment (MDVI); Assessment; Sequential Explanatory Mixed Methods.

\section{Introduction}

A baby expresses herself to adults by crying, smiling, moving her body to show comfort/discomfort, using facial expressions and gestures much before she begins to use words (Brady, Steeples and Fleming, 2005). Seeing the response of the adults in her life to these behaviors, the baby gradually demonstrates more complex preverbal communication behaviors such as reaching, manipulating and pointing to the objects. Her mother supports the baby's preverbal communication behaviors by looking at her face, smiling at her, talking to her and responding to her smiles and vocalization. In this way, preparation for verbal communication starts through preverbal communication behaviors in the early stages of infancy (Chen, 2002; Rowland and Schweigert, 2005, p. 415; Rowland and Stremel-Campbell, 1987, p.50; Topbaş, 2008). If a child has a condition or disability which affects her development, the child's communication skills can be damaged severely (Cushman, 1992). The characteristics of expressive communication skills of TD children in the first two years of their lives, which is known as the preverbal period, have an important role in our understanding of the interaction of children with MDVI (Rowland and Schweigert, 2005, p. 415; Rowland and Stremel-Campbell, 1987, p.50). Children with MDVI have difficulty develop a good communication skills due to their sensory loss and the disadvantage of receiving information while a TD child improve her communication skills by interacting with the people and objects around her. Thus children with MDVI are disadvantaged compared to their peers in the appropriate age range (Holte et al., 2006).

In typical development, regulating behaviors, social interaction and joint attention skills are the crucial foundations of verbal communication, contributing to our understanding of how children with MDVI communicate with their environment during the preverbal communication period (Mundy et al., 2003; Mundy and Stella, 2000; Tomasello, 1995; Topbaş, Maviş and Erbaş, 2003; Westling and Fox, 2004, p. 264). Regulating behaviors are expressing the physiological needs, comfort/discomfort and interests with the various preverbal behaviors such as facial expressions, body movements, vocalizations and etc. (Brady, Steeples and Fleming, 2005; Crais, Watson and Baranek, 2009; Topbaş, Maviş and Erbaş, 2003), social interaction is a process for learning the mutual communication skills behaviors such as taking turns, giving and maintaining attention, to say hello and goodbye by observing adults' behaviors (Crais, Watson and Baranek, 2009; Stillman and Battle, 1985) and joint attention is to maintain the attention on an object or event with another person and typically involves the sharing mutual interest (Schartz and Odom, 2004). During the realization of joint attention both persons who share the interest on the object or event are aware that they are giving attention to the same thing (Tomasello, 1995). These three concepts are giving us a good idea about how the young children as well as the children with disabilities functionally communicate without words (Crais, Watson and Baranek, 2009; Topbaş, Maviş and Erbaş, 2003).

Development of preverbal communication starting from birth to two years in typical development is examined in seven stages. These stages are (Bates et al., 1979; Rowland and Schweigert, 2005, p. 416; Rowland and Stremel-Campbell, 1987, p. 52):

(1) Pre-intentional behaviors (0-3 months): Child's behavior is not yet communicative and under her control. Reflexive and impulsive behaviors according to her physiological state (hunger, comfort, pain, etc.) are seen.

(2) Intentional behaviors (3-8 months): Child's behaviors, which are more controlled and intentional, interpreted by the mother/caregiver cause they are not communicative yet. 
Ayylldı, E., Akçin, N., \& Güven, Y. (2016). Development of Preverbal Communication Skills Scale for Children with Multiple Disabilities and Visual Impairment. Journal of Human Sciences, 13(2), 2668-2681. doi:10.14687/ihs.v13i2.3718

(3) Unconventional pre-symbolic communication (6-12 months): Unconventional and socially unappropriate behaviors such as whining, screaming, throwing things, biting etc. occurs in order to get adults attention intentionally.

(4) Conventional pre-symbolic communication (12-18 months): Natural and conventional gestures such as smiling, waving, shaking head for approve or reject, lifting arms to be bosom, and etc.

(5) Concrete symbolic communication (12-24 months): It is difficult to distinguish this stage from the previous one. Child begins to understand the relationship between the object and the sign which represents it. For example, the child touch or smack her mouth when she wants to eat.

(6) Abstract symbolic communication (12-24 months): Child starts to express herself with a single sign/word, but she still uses natural gestures and body movements with the verbal expression.

(7) Formal symbolic communication ( 24 months + ): Child begins to understand the grammer of the language and starts to speak with using two or more signs/words.

It is known that children with MDVI are far behind from their peers in many developmental areas due to the number and combinations of their disabilities. Their ability to communicate in a meaningful and functional way is especially very limited. Most children with MDVI exhibit idiosyncratic behaviors when they interact with their environment, stay at the preverbal communicaton level in a very long period of time and the majority of them may never acquire verbal communication skills at all (Olsson 2006; Rowland 2009; Rowland and Schweigert 2005, p. 418; Rowland and Stremel-Campbell 1987, p.54). Thus, it is very crucial to recognize the unique, individual communication behaviors of these children, in order to support their verbal communication skills. Studies show that if families and educators take into consideration the communicative behaviors of children with MDVI, their verbal communication skills could be improved (Janssen, Riksen-Walraven and Van Dijk 2006). However, before we teach proper communication skills and improve communicative behaviors, it is necessary to evaluate the preverbal communication with the appropriate assessment methods. The success of training and the implementation process of appropriate education should be based on suitable and sufficient assessment of performance (Clark Gerken 2004; Westling and Fox 2004, p. 266).

The assessment of children with MDVI communication skills is quite challenging because they have more than one disability and/or disorder and most of them also suffer from serious health problems (Bruce, Godbold and Naponelli-Gold, 2004; Crais and Roberts, 1996). There is a variety of assessment tools for assessment of communication, ranging from the formal methods such as standardized and non-standardized tests and scales (Crais, Watson, Baranek, 2009) to informal ones such as interviews, observations, family and teacher reports, Individualized Education Programs (IEP) reviews, previous reports and information, portfolios, and video recording (Crais and Roberts, 1996; Warner and Wolf Nelson, 2004).

The standardized tests and scales such as Reynell Developmental Language Scale (Reynell and Gruber, 1990) and Receptive-Expressive Emergent Language Test (Bzoch and League, 1991) which assess the language and communication development in children with developmental delays are not appropriate for evaluating communication skills of children with MDVI, while the nonstandardized tests and scales such as Callier-Azusa Scale H Form (Stillman and Battle, 1985) and Communication Matrix (Rowland, 2009), are especially used for evaluating these children's preverbal communication behaviors.

Various studies have been performed to examine preverbal communication behaviors of children with MDVI with informal assessment methods (Iacono, Carter and Hook, 1998; Mallineni et. al., 2006; McLaughlin and Cascella, 2008; Narayan and Bruce, 2006; Rainey Perry, 2003; Rowland, 1984; Wilder, 2008). On the other hand, evaluation of preverbal communication skills of children with MDVI with informal assessment tools brings a great disadvantage in terms of the generalization of the study results because of the small number of participants. Since these studies 
Ayylldı, E., Akçin, N., \& Güven, Y. (2016). Development of Preverbal Communication Skills Scale for Children with Multiple Disabilities and Visual Impairment. Journal of Human Sciences, 13(2), 2668-2681. doi:10.14687/jhs.v13i2.3718

were not performed with longitudinal research methods, it is also hard to generalize the study results against the whole population. The heterogeneity of the numbers, types and combinations of disabilities that the children with MDVI lead only to the interpretation of research findings, depending on the study groups observed during research.

The need for assessment of preschool children has grown dramatically in the past two decades following the implementation special education services for infants, toddlers, and preschoolers (Mahone, 2005). On the other hand, in Turkey, multiple disabilities is not a recognized special education category and the interest on this area is quite unsatisfactory. Considering the studies performed with the children with MDVI, the lack of an assessment tool to evaluate the preverbal communication skills of these children in Turkey was seen as a problem.

\section{Purpose}

The purpose of the study is to develop a valid and reliable scale which evaluate preverbal communication skills of children with MDVI. The study was started with the qualitative phase in order to collect in-depth information about preverbal communication behaviors of children with MDVI with semi-structed interviews and the scale was developed using the quantitative collection and analysis. After the development of the PCSS-MDVI, a validity and reliability analysis was performed with a larger simple in the quantitative phase of the study.

The sub-goals of the qualititative phase are as follows:

1. What kind of preverbal communication behaviors that the children with MDVI use for regulating behaviors (expression of physiological needs, comfort/discomfort, interest)?

2. What kind of preverbal communication behaviors that the children with MDVI use for social interaction?

3. What kind of preverbal communication behaviors that the children with MDVI use for joint attention?

The sub-goals of the quantitative phase are as follows:

1. Is the PCSS-MDVI a valid scale?

2. Is the PCSS-MDVI a reliable scale?

\section{Method and material}

\subsection{Research Model}

In this study, mixed methods of sequential explanatory design was used which is based on using a combination of qualitative and quantitative research methods. The rationale of using sequential explanatory design in the research for instrument development is to refine and expand the results of qualitative study by using a quantitative research method afterwards (Creswell 2009, p. 211). In the qualitative phase of this study, the preverbal communication behaviors of children with MDVI were explored by using semi-structured interviews. Then based on the findings of the quantitative phase and the relevant literature, it was targeted to develop the items to be used in PCSS-MDVI. In the quantitative phase, an analysis of the validation and the reliability of the scale were performed.

Figure 1.

Development of the scale with a mixed methods sequential explanatory design

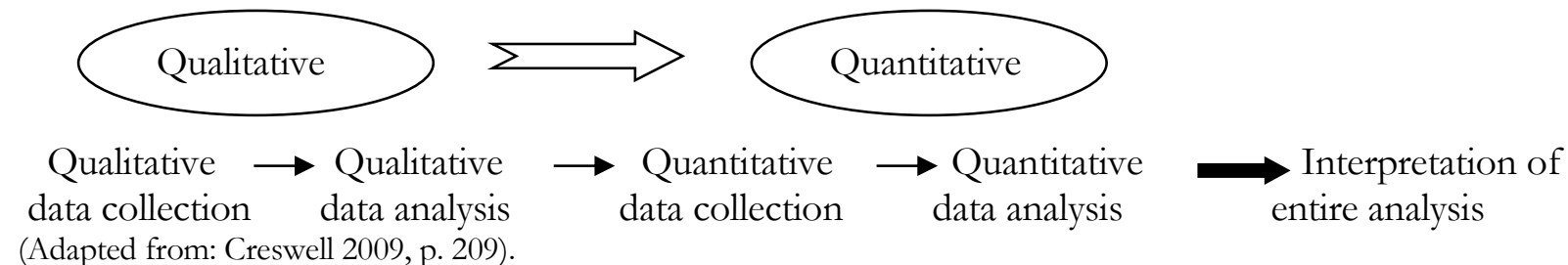


Ayylldı, E., Akçin, N., \& Güven, Y. (2016). Development of Preverbal Communication Skills Scale for Children with Multiple Disabilities and Visual Impairment. Journal of Human Sciences, 13(2), 2668-2681. doi:10.14687/jhs.v13i2.3718

\subsection{Qualitative Phase: Interview}

The purpose of the qualitatitive phase of the study was to determine the preverbal communication skills of children with MDVI as reported by their mothers. Case study approach was used as the qualitative inquiry strategy. Case studies provide intensive, detailed and in-depth information about an individual or a group using a variety of data collection procedures such as interviews, observations and video records and it is often prefered and used for special education studies (Creswell, 2009, p. 177; Mertens and McLaughlin, 1995, p. 51). So, semi-structed interviews were conducted with the mothers of children with MDVI to gain information about the preverbal communication skills of their children.

\subsubsection{Study Sample: Sample 1}

Due to children with MDVI constituting a unique group of individuals because of the personal characteristics and combinations of disabilities possessed by each child, MDVI is a low incidence special education category (Thuppal and Sobsey 2006, p. 312; Vlaskamp and Cuppen-Fontaine 2007). The interviewees (mothers of children with MDVI) were chosen using the intensity and criterion sampling methods (Patton 2002, p. 230; Yıldırım and Şimşek, 2008, p.107). The cases with identified criterias are included to the study in criterion sampling method. These criterias for the cases are pre-determined in order to obtain more and detailed information about the aim of the research and the cases having these criterias are intentionally included to the study (Büyüköztürk, Kılıç Çakmak, Akgün, Karadeniz ve Demirel, 2011, p. 91; Patton, 2002, p. 230; Yıldırım ve Şimşek, 2008, p.112). The qualitative phase criterias were: (1) the respondents are the mothers' of children with MDVI, (2)the respondents' children should not be deaf or have a hearing impairment which severely affects their verbal communication skills, (3) the respondents' children should have some degree of visual loss with additional problems such as intellectual disability, physical disability, Cerebral Palsy, autism, autism like behaviors, neurological, emotional and/or behavioral problems and health conditions (The disability types of the children with MDVI from sample 1 were determined by examining their medical reports, IEP's, and family and teacher reports), (4) the respondents' children are the ones who are receiving education in a school for the blind or in special education and rehabilitation centers in Istanbul, as well as the ones who are not receiving any educational support at all.

Intensity sampling involves selecting the participants from the rich cases which are intensely demonstrated the unique characteristics of the whole group (Patton, 2002, p. 234). The children with MDVI constitute a unique group in the general special education population because of their individual features (Thuppal and Sobsey, 2006, p. 312; Vlaskamp and Cuppen-Fontaine, 2007). So these children's preverbal communication skills were examined very detailed through interviewing with their mothers and the results which gained from sample 1 were discussed only for this group which has characteristics features of children with MDVI.

The interview guide which has questions about the preverbal communication behaviors of children with MDVI was conducted during face to face meetings. Totally 34 mothers of children with MDVI participated in the study. The children age range was 4 to 13 years old (12 female, 22 male). The characteristics of the respondent's and their children can be seen in Table 3.1. 
Ayylldı, E., Akçin, N., \& Güven, Y. (2016). Development of Preverbal Communication Skills Scale for Children with Multiple Disabilities and Visual Impairment. Journal of Human Sciences, 13(2), 2668-2681. doi:10.14687/jhs.v13i2.3718

Tablo 3.1.

The Characteristics of the Interviewees and Their Children with MDVI

\begin{tabular}{|c|c|c|c|c|c|c|}
\hline \multicolumn{2}{|l|}{ Mother } & \multirow[b]{2}{*}{$\begin{array}{l}\text { Education } \\
\text { Status } * *\end{array}$} & \multirow[b]{2}{*}{ Occupation } & \multicolumn{2}{|c|}{ MDVI Child } & \multirow[b]{2}{*}{ Disability Type *** } \\
\hline $\begin{array}{l}\text { Code } \\
\text { name * }\end{array}$ & Age & & & Age & Gender & \\
\hline Zeynep & 32 & Primary & Housewife & 8 & Boy & VI+Physical+Intellectual+Special syndrome \\
\hline Sinem & 33 & Primary & Housewife & 8 & Boy & VI+Intellectual \\
\hline Gözde & 42 & Primary & Housewife & 6 & Boy & VI+Physical+Intellectual+Epilepsy \\
\hline Serap & 33 & Primary & Housewife & 13 & Girl & VI+Intellectual \\
\hline Nazan & 48 & High & Freelancer & 10 & Boy & VI+Physical+Intellectual+Cerebral Palsy \\
\hline Nurten & 40 & Primary & Housewife & 9 & Girl & VI+Intellectual+Special syndrome \\
\hline İpek & 37 & Primary & Housewife & 10 & Girl & VI+Intellectual \\
\hline İpek & 37 & Primary & Housewife & 10 & Boy & VI+Intellectual \\
\hline Aliye & 35 & Primary & Housewife & 12 & Boy & VI+Intellectual+Autism \\
\hline Nazlı & 39 & Primary & Housewife & 9 & Boy & VI+Intellectual \\
\hline Birsen & 32 & University & Private sector staff & 4 & Boy & VI+Intellectual \\
\hline Öykü & 47 & Primary & Housewife & 9 & Girl & VI+Intellectual+Cerebral Palsy \\
\hline Nehir & 40 & Primary & Housewife & 12 & Boy & VI+Intellectual+Cerebral Palsy+Autism like behaviors \\
\hline Nuran & 34 & Primary & Housewife & 6 & Boy & VI+Intellectual+Cerebral Palsy+Chronic illness \\
\hline Hatice & 29 & Primary & Housewife & 9 & Boy & VI+Intellectual+Cerebral Palsy \\
\hline Nurşen & 31 & Primary & Hairdresser & 7 & Girl & VI+Intellectual+Cerebral Palsy \\
\hline Fatma & 46 & Primary & Quality controller & 11 & Girl & VI+Intellectual+Autism like behaviors \\
\hline Selin & 34 & Primary & Housewife & 8 & Boy & VI+Physical+Intellectual+Autism like behaviors \\
\hline Ela & 50 & University & Retired & 10 & Girl & VI+Intellectual+Cerebral Palsy \\
\hline Hanife & 49 & High & Housewife & 10 & Boy & VI+Intellectual \\
\hline Mehtap & 34 & University & Teacher & 9 & Boy & VI+Cerebral Palsy + Autism like behaviors \\
\hline Petek & 36 & Primary & Housewife & 9 & Boy & VI+Intellectual+Cerebral Palsy+Epilepsy \\
\hline Nisa & 39 & Primary & House maid & 11 & Girl & VI+Intellectual+Autism like behaviors+Epilepsy \\
\hline Neslihan & 31 & Primary & Housewife & 6 & Girl & VI+Intellectual+Cerebral Palsy \\
\hline Naciye & 33 & Primary & Housewife & 8 & Boy & VI+Intellectual+Autism like behaviors \\
\hline Lila & 38 & Primary & Housewife & 11 & Boy & VI+Intellectual+Autism like behaviors+Epilepsy \\
\hline Derin & 34 & University & Housewife & 9 & Boy & VI+Physical+Intellectual+ Special syndrome \\
\hline Perihan & 32 & University & Housewife & 4 & Girl & VI+Intellectual+Cerebral Palsy \\
\hline İlknur & 43 & Primary & Housewife & 13 & Boy & VI+Intellectual+Epilepsy \\
\hline Göksu & 36 & Primary & Housewife & 10 & Girl & VI+Physical+Intellectual \\
\hline Tuğçe & 33 & High & Housewife & 7 & Boy & VI+Intellectual+Cerebral Palsy+Epilepsy \\
\hline Yasemin & 41 & University & Teacher & 13 & Boy & VI+Intellectual \\
\hline Derya & 33 & Primary & Housewife & 13 & Girl & VI+Intellectual+Autism like behaviors \\
\hline Beyza & 32 & High & Housewife & 9 & Boy & VI+Intellectual+Cerebral Palsy \\
\hline
\end{tabular}

* Mothers are given code names in order to protect their privacy.

** The education status are abbreviated as follows: Primary: Primary school graduate, High: High school graduate, University: University graduate.

*** Some of the disability types are abbreviated as follows: VI: Visual Impairment, Physical: Physical disability, Intellectual: Intellectual disability

\subsubsection{Data Collection}

After researching relevant literature about communication skills of children with MDVI and obtaining the views of three field experts (two university staff members and one special education teacher), 36 open-ended interview questions were purposefully grouped under three main headings as regulating behaviors, social interaction and joint attention skills, these forming the foundation of verbal communication and having an important role in reciprocal communication (Mundy et al., 2003; Mundy and Stillman, 2000; Stillman and Battle, 1985; Tomasello, 1995, Topbaş, Maviş and Erbaş, 2003; Westling and Fox, 2004, p. 263) were prepared. Most of the interviews took place in the first author's office in the school for the blind, with the remainder taking place in the homes of children with MDVI. The aim of the study and the Information Form were introduced to the interviewees and the permissions for interview and audiotape process were granted using a consent form. To begin with, the interviewees were assured about confidentiality and asked related questions, with the responses being audiotaped. The question guide included the questions under 
Ayylldı, E., Akçin, N., \& Güven, Y. (2016). Development of Preverbal Communication Skills Scale for Children with Multiple Disabilities and Visual Impairment. Journal of Human Sciences, 13(2), 2668-2681. doi:10.14687/ihs.v13i2.3718

three main headings, regulating behavior (e.g., How does your child show you that she/he is hungry?), social interaction (e.g., How does your child respond to the sounds around her/?) and joint attention (e.g., How does your child show you the toys and objects she/he is interested in?)

\subsubsection{Data Analysis}

The record files of the interviews were transferred to a computer and transcribed verbatim. Descriptive analysis was performed on the findings of the interviews. First, all transcriptions are read carefully, then significant and repeated statements were determined from the three main headings which were specified from the beginning of the study in order to prepare the coding keys for the questions. The coding keys and about 30\% of the interview forms were given to a field expert (a special education teacher) to determine the inter-rater reliability. To calculate the percentage of inter-rater reliability (agreements/agreements+disagreements)X100 formula is used. The range of the inter-rater reliability percentages were between $70 \%$ to $100 \%$ and the mean of the inter-rater reliability was $89,5 \%$.

\subsection{Interim Phase: Scale Development}

The development of the PCSS-MDVI was the interim phase of the study. In this phase, researchers aimed to develop the items and the scoring guide of PCSS-MDVI both based on the findings from the qualitative phase and the relevant literature. An information form also was designed in order to determine the demographic characteristics of the quantitative stage participants such as age, gender, duration of education, number and type and degree of disabilities.

The guidelines devised by Creswell (2009, p. 146) was used for the scale development. The findings from the qualitative phase provided in-depth information about preverbal communication behaviors of children with MDVI. The item pool prepared utilizing the interview results was then examined by the field expert (a special education teacher) and the pilot study which was conducted with two respondents, the number of questions on the scale substance was identified as 17 . The scale has three subscales, 5 items of behavior regulation (e.g., item number 4, How does your child show you that she has pain?), 9 items of social interaction (e.g., item number 8 , How does your child say hello to (greet) the people that she knows?) and 3 items of joint attention (e.g., item number 16, How does your child take your attention to a sound like speech, music, doorbell, outside noise?). The answers from the mothers to the 17 open-ended scale items were scored according to the scoring guide (Table 3.2) which was prepared by taking consideration the seven stages of preverbal communication covering the first two years of life in typical development (Rowland and Stremel-Campbell, 1987, p.52). The subscales are in order of the developmental sequence and the items of the scale and the scoring of the responses are based on the seven developmental stages of preverbal communication. The examples of one of the item from the scale and the possible answers for scoring this item are as follows.

PCSS-MDVI Item number 4, "How does your child show you that she has pain?"

1 point: 'She has no reaction to anyone or anything'... 'I can not tell if she has pain from looking her behaviors'... 'She does nothing to show me if she has pain'.

2 points: 'She rubbs her arm when she has pain'... 'She whines'... 'She holds her head constantly if she has pain'... 'She cries while she holds the body part which sore'.

3 points: 'She throws herself down'... 'Yells, attacks'... 'She hits the doors, the windows, hits me, hits herself.

4 points: 'Vocalizes to indicate her pain, like Ihhh Ihhh'...

5 points: 'She takes my hand to the body part which sore like her ear'... 'She put her hand to her mouth when I ask if she had a tooth ache'... 'She shows the sore body part for me to kiss'.

6 points: 'She says "Hurts"'... 'When I ask her, she says "Pain"'.

7 points: 'She says "Stomach hurts"'... 'She says "I have headache"'... 'She says "Have fever, look"'. 
Ayylldı, E., Akçin, N., \& Güven, Y. (2016). Development of Preverbal Communication Skills Scale for Children with Multiple Disabilities and Visual Impairment. Journal of Human Sciences, 13(2), 2668-2681. doi:10.14687/ihs.v13i2.3718

\subsection{Quantitative Phase: Validation and Reliability of PCSS-MDVI}

The purpose of the quantitative phase was to complete the validation of PCSS-MDVI with a larger sample and investigate if PCSS-MDVI is a valid and reliable scale. Hence, PCSS-MDVI study was conducted with 65 mothers of children with MDVI.

\subsubsection{Study Samples: Sample 2 and 3}

There were two samples of the quantitative phase. Sample 2 was purposely selected by using criterion and intensity sampling methods and included 65 mothers of children with MDVI. The criterias were the same as the Sample 1. The children with MDVI age range was 1 to 16 years old (27 female, 38 male). All the mothers of children with MDVI who participated to the qualitative phase of the study were also involved in the scale validation process. The other were the mothers of children with MDVI from the schools for the blind in Istanbul and Ankara, and the special education and rehabilitation centers.

Sample 3 consisted of 34 mothers of TD children. The TD children age range was 1 to 24 months old (20 female, 14 male). In order to reach TD children, first author made contact with couple of pediatricians and by explaining the aim of the study got permission from the mothers whose bring their babies to these pediatricians and administer the scale to the mothers who are agreed to participate the study.

The reason the TD children were included in the study was to determine the relevance of the scale if it covered the preverbal language period between 0-24 months and to investigate the difference of preverbal communication development between the children with MDVI and the TD children.

\subsubsection{Data Collection}

65 mothers of children with MDVI were invited to participate in the study through phone calls and the purpose and the procedures of the study were explained. The questions of the scale were given to the mothers who agreed to participate in the study voluntarily in face-to-face meetings. PCSS-MDVI was also conducted with 34 TD children's mothers and this data was used for the reliability analysis. The mothers from both samples were given enough time to think about the questions.

The administration of the scale were took 10 to 20 minutes and took place in the schools for the blind in Istanbul and Ankara, and couple of special education and rehabilitation centers. TD children's mothers are visited in their houses in order to give them the scale. First, the aim of the study were introduced and the Information Form and the scale were filled with the participants.

\subsubsection{Data Analysis}

Item analysis, and checking the validity and reliability of the scale was completed. The content validity of the scale was provided with the expert views. The analysis for validation were as follows: The correlation between the subscales scores of children with MDVI with each other and the correlation between the total scale scores and the subscales scores of children with MDVI were analysed with the Pearson Correlation Test. The Pearson Correlation Test was also used for determining the correlation between the total scale and subscales scores and the ages, duration of education and degree of disabilities of children with MDVI. Mann-Whitney U Test was used to examine the differentiation between the total scale and subscales scores of children with MDVI and TD children. For differentiation validity, disparity between two groups who had the highest and the lowest scores of $27 \%$ from the scale was examined. For the reliability of the scale, Cronbach's alpha coefficients were calculated and to determine the inter-rater reliability (Cooper, Heron and Heward 1987). $30 \%$ of the completed forms of the scale were selected randomly and given to a field expert (a special education teacher) for re-scoring. 

Multiple Disabilities and Visual Impairment. Journal of Human Sciences, 13(2), 2668-2681. doi:10.14687/jhs.v13i2.3718

\section{Results}

\subsection{Qualitative Phase}

The interviews were conducted with 34 mothers and 36 open-ended questions about communication behaviors of children with MDVI were asked. The findings of the qualitative phase of the study showed that despite the chronological age of children with MDVI, these children have been using preverbal communication behaviors such as facial expressions, body movements, gestures, vocalizing, stereotipical behaviors for express interest and requests and those behaviors were mostly idiosyncratic. Results also indicated that children with MDVI have limited regulating behaviors and their social interaction and joint attention skills were severely underdeveloped.

\subsection{Quantitative Phase}

65 mothers of children with MDVI were given PCSS-MDVI which was developed based on relevant literature and by using results of the interviews. The following analysis was conducted in order to provide validity and reliability of the scale.

\subsubsection{Item Analysis}

Results of the item analysis showed that item-total correlations of all items were above .20, so discriminatory power of the items are very high and all the items are reliable in order to evaluate the preverbal communication behaviors of children with MDVI. The answers for each item from the groups who had the highest and the lowest scores of $27 \%$ from the scale were compared with the ttest for independent groups (this analysis also gave the differentiation validity). The findings indicated that there is a significant difference between the highest and the lowest groups and the distinctiveness of the items were highly significant (Table 4.3).

Table 4.3.

Item Total Score Correlations of PCSS-MDVI and the t-Test for Independent Groups Results

\begin{tabular}{lll}
\hline Item number & Item Total Score Correlations & $\mathbf{t}$ \\
\hline 1 & .69 & $-8,356^{*}$ \\
2 & .69 & $-7,445^{*}$ \\
3 & .79 & $-12,353^{*}$ \\
4 & .68 & $-6,371^{*}$ \\
5 & .53 & $-5,368^{*}$ \\
6 & .82 & $-10,140^{*}$ \\
7 & .65 & $-3,875^{*}$ \\
8 & .53 & $-3,643^{*}$ \\
9 & .60 & $-4,040^{*}$ \\
10 & .79 & $-10,995^{*}$ \\
11 & .77 & $-10,496^{*}$ \\
12 & .62 & $-5,384^{*}$ \\
13 & .72 & $-6,993^{*}$ \\
14 & .75 & $-9,174^{*}$ \\
15 & .71 & $-8,938^{*}$ \\
16 & .75 & $-7,678^{*}$ \\
17 & .64 & $-7,019^{*}$ \\
\hline
\end{tabular}

Note. ${ }^{*} \mathrm{p}<.00$ 
Ayylldı, E., Akçin, N., \& Güven, Y. (2016). Development of Preverbal Communication Skills Scale for Children with Multiple Disabilities and Visual Impairment. Journal of Human Sciences, 13(2), 2668-2681. doi:10.14687/jhs.v13i2.3718

\subsubsection{Construct Validity}

Results with respect to construct validity showed that the correlation between the subscales scores of children with MDVI with each other and the correlation between the children with MDVI's total scale and the subscale scores are highly significant. The correlation between total scale and subscales scores of children with MDVI and the duration of education received is close to significant interms of regulating behaviors, but there is no such relationship found for the rest. Significantly negative correlation is found between the total scale and subscales scores of children with MDVI and the degree of disabilities. Videlicet, the total scale and subscale scores decrease if the degree of disabilities increase. Finally, the correlation between children with MDVI's total scale and subscales scores and their chronological ages is not significant, while the correlation between TD childrens' total scale and subscales scores and their chronological ages is highly significant, yet the TD childrens' total scale and subscales scores increase parallel with their ages, as expected (Table 4.4).

Table 4.4.

Pearson Correlation Tests Results for Children with MDVI and TD Children

\begin{tabular}{|c|c|c|c|c|c|c|c|c|}
\hline & & $\begin{array}{l}\text { Regulating } \\
\text { behaviors }\end{array}$ & $\begin{array}{l}\text { Social } \\
\text { interaction }\end{array}$ & $\begin{array}{l}\text { Joint } \\
\text { attention }\end{array}$ & $\begin{array}{l}\text { Total } \\
\text { Score }\end{array}$ & Age & $\begin{array}{l}\text { Duration of } \\
\text { Education }\end{array}$ & $\begin{array}{l}\text { Degree of } \\
\text { disabilities }\end{array}$ \\
\hline $\begin{array}{l}\text { Children } \\
\text { with } \\
\text { MDVI }\end{array}$ & $\begin{array}{l}\text { Regulating behaviors } \\
\mathrm{p} \\
\text { Social interaction } \\
\mathrm{p} \\
\text { Joint attention } \\
\mathrm{p} \\
\text { Total score } \\
\mathrm{p} \\
\text { Age } \\
\mathrm{p} \\
\text { Duration of education } \\
\mathrm{p} \\
\text { Degree of disabilities } \\
\mathrm{p}\end{array}$ & - & $\begin{array}{l}802 \\
, 00 \\
-\end{array}$ & $\begin{array}{l}, 671 \\
, 00 \\
, 774 \\
, 00 \\
-\end{array}$ & $\begin{array}{l}908 \\
, 00 \\
, 963 \\
, 00 \\
, 856 \\
, 00 \\
-\end{array}$ & $\begin{array}{l}, 223 \\
, 07 \\
, 207 \\
, 09 \\
, 148 \\
, 23 \\
, 217 \\
, 08 \\
\end{array}$ & $\begin{array}{l}, 240 \\
, 054 \\
, 157 \\
, 21 \\
, 155 \\
, 21 \\
, 199 \\
, 11\end{array}$ & $\begin{array}{l}-, 443 \\
, 00 \\
-, 278 \\
, 02 \\
-, 335 \\
, 00 \\
-, 372 \\
, 00\end{array}$ \\
\hline $\begin{array}{l}\text { TD } \\
\text { children }\end{array}$ & $\begin{array}{l}\text { Regulating behaviors } \\
\mathrm{p} \\
\text { Social interaction } \\
\mathrm{p} \\
\text { Joint attention } \\
\mathrm{p} \\
\text { Total score } \\
\mathrm{p} \\
\text { Age } \\
\mathrm{p}\end{array}$ & - & $\begin{array}{l}894 \\
, 00 \\
- \\
927 \\
, 00 \\
, 981 \\
, 00\end{array}$ & $\begin{array}{l}, 896 \\
, 00 \\
-\end{array}$ & $\begin{array}{l}, 956 \\
, 00 \\
-\end{array}$ & $\begin{array}{l}926 \\
, 00 \\
, 894 \\
, 00 \\
914 \\
, 00 \\
, 937 \\
, 00 \\
\end{array}$ & & \\
\hline
\end{tabular}

The Mann-Whitney U Test was used to examine the differentiation between the children with MDVI and TD children's total scale and subscales scores. The total scale and two of the subscales, regulating behaviors and social interaction scores increase significantly in favor of TD children with the increase of chronological age, as shown in Table 4.5. No age-related differences joint attention scores was found. 
Ayylldı, E., Akçin, N., \& Güven, Y. (2016). Development of Preverbal Communication Skills Scale for Children with Multiple Disabilities and Visual Impairment. Journal of Human Sciences, 13(2), 2668-2681. doi:10.14687/ihs.v13i2.3718

Table 4.5.

Pearson Correlation Tests Results for Children with MDVI and TD Children

\begin{tabular}{lllll}
\hline & $\begin{array}{l}\text { Regulating } \\
\text { behaviors }\end{array}$ & Social interaction & Joint attention & Total scale score \\
\hline $\mathrm{Z}$ & $-3,611$ & $-2,269$ &,- 872 & $-2,536$ \\
$\mathrm{p}$ &, 00 &, 02 &, 38 &, 01 \\
\hline
\end{tabular}

\subsubsection{Reliability}

Cronbach's alpha coefficients and the inter-rater reliability were computed for reliability determination. According to the results, the internal reliability coefficients (Table 4.6) were significantly high.

Table 4.6.

Cronbach's Alpha Coefficients of Subscales and Total Scores for the Samples of Qualitative Phase

\begin{tabular}{lllll}
\hline & & N & Item (n) & $\alpha$ \\
\hline & Children with MDVI & 65 & 17 &, 94 \\
& TD children & 34 & 17 &, 97 \\
& Both groups & 99 & 17 &, 96 \\
\hline Subscales & Regulating behaviors & 65 & 5 &, 86 \\
(Children with & Social interaction & 65 & 9 &, 91 \\
MDVI ) & Joint attention & 65 & 3 &, 84 \\
\hline
\end{tabular}

The inter-rater reliability percentages ranged from $80 \%$ to $100 \%$, and the mean inter-rater reliability percentage was $90,29 \%$.

The overall results of the qualitative phase of the study revealed that the PCSS-MDVI is a valid and reliable assessment tool for evaluating preverbal communication skills of children with MDVI.

\section{Conclusions and recommendations}

As clearly demonstrated in the literature, children with MDVI have severe difficulties especially in acquiring verbal communication skills and communicating appropriately and effectively with their environment. This situation is frequently reported by the parents and the teachers as a serious problem and leads to the prevention of proper planning for and implementation of the child's education. Most of the children with MDVI experience various behavioral, social and psychological problems due to their difficulties in communicating, despite their increasing age. This adversely affects the learning opportunities for the child both at home and at school (Cushman, 1992; Rowland and Schweigert, 2005, p. 418; Downing, 2004, p. 552).

In this sequential explanatory mixed methods study, researchers aimed to develop a valid and reliable scale to assess preverbal communication of children with MDVI. Interviews were performed with 34 mothers of children with MDVI in the quantitative phase. In the qualitative phase, the questions in the scale questionnaire were prepared by considering into the results of the interviews and relevant literature. After the revision of the field experts and the pilot study, the scale named Preverbal Communication Skills Scale for Children with MDVI (PCSS-MDVI) and it was conducted with the mothers of 65 children with MDVI and 34 TD children. The analysis regarding the item analysis, validity and reliability of the scale were completed in the last step of the study. 
Ayylldı, E., Akçin, N., \& Güven, Y. (2016). Development of Preverbal Communication Skills Scale for Children with Multiple Disabilities and Visual Impairment. Journal of Human Sciences, 13(2), 2668-2681. doi:10.14687/jhs.v13i2.3718

This study is a preliminary work of development of PCSS-MDVI, since the scale was developed only by taking consideration the children with MDVI mother's opinions about their children's preverbal communication behaviors. Having the limited number of respondents to the scale is also another limitation of the study and one should consider the results carefully because of that. In next step, it is planned to add the video recording analysis of children with MDVI's preverbal communication behaviors and enhance the number of respondents in order to improve the PCSS-MDVI.

\subsection{Usability of study results}

It is very important for the parents, educators, health professionals and other service providers to be aware and informed of and preferably trained for noticing, observing and evaluating the preverbal communication behaviors of children with MDVI, because by supporting preverbal communication behaviors, verbal communication skills of these children can be improved. The PCSS-MDVI can be used to assess communication skills of children with MDVI as well as the other non-verbal children who have developmental disabilities such as intellectual disabilities and autism, if the validity and reliability analysis are performed for these groups.

\section{References}

Bates, E., Benigni L., Bretherton, I., Camaioni, L. \& Volterra, V. (1979). "Cognition and communication from nine to thirteen months: Correlational findings", The emergence of symbols cognition and communication in infancy, Edts., E. Bates, L. Benigni, I. Bretherton, L. Camaioni \& V. Volterra, New York: Academic Press Inc.

Brady, N. C., Steeples,T. \& Fleming, K.,(2005). "Effects of prelinguistic communication levels onlevels on initiation and repair of communication in children with disabilities", Journal of Speech, Language, and Hearing Research, 48 (5), 1098-1113.

Bruce, S., Godbold, E. \& Naponelli-Gold, S. (2004). "An analysis of communicative functions of teachers and their students who are congenitally deafblind", RE:view. 36 (2), 81-90.

Büyüköztürk, Ş., Kılıç Çakmak, E., Akgün, Ö. E., Karadeniz, Ş. ve Demirel, F., (2011). Bilimsel Arastırma Yöntemleri, 8. Baskı. Ankara: Pegem Akademi.

Chen, D. (2002). "Encouraging early communication", Understanding deafblindness: Issues, perspectives and strategies, Edt, L. Alsop, USA: Hope, Inc.

Clark Gerken, K. (2004). "Assessment of preschool children with severe disabilities", Psycho educational assessment of preschool children, Edt., B. A. Bracken, Third Edition, New Jersey: Lawrence Erlbaum Associates, Inc., Publishers.

Cooper, J. O., Heron, T. E. \& Heward, W. L. (1987). Applied behavior analysis, Upper Saddle River, NJ: Prentice-Hall.

Crais, E. R. \& Roberts, J. (1996). “Assessing communication skills”, Edts., M. McLean, D. B. Bailey \& M. Wolery, Assessing infants and preschoolers with special needs, Second Edition, Upper Saddle River, NJ: Merrill/Prentice Hall.

Crais, E.R., Watson, L. R.\& Baranek, G. T. (2009). "Use of Gesture Development in Profiling Children's Prelinguistic Communication Skills", American Journal of Speech-Language Pathology, $18,95-108$.

Creswell, J. W. (2009). Research design: Qualitative, quantitative, and mixed methods approaches, Third Edition, California: Sage Publications Ltd. 
Ayylldı, E., Akçin, N., \& Güven, Y. (2016). Development of Preverbal Communication Skills Scale for Children with Multiple Disabilities and Visual Impairment. Journal of Human Sciences, 13(2), 2668-2681. doi:10.14687/jhs.v13i2.3718

Cushman, C. (1992). "Language and Cognition", Perkins activity and resource guide. A handbook for teachers and parents of students with visual and multiple disabilities, Edts., C. Cushman, K. Heydt, S. Edwards, M. J. Clark \& M. Allon, Volume 1, Massachusetts: Perkins School for the Blind.

Downing, J. E. (2004). "Communication skills", Educating children with multiple disabilities: A collaborative approach, Edts., F. P. Orelove, D. Sobsey \& R. K. Silberman, Baltimore: Paul Brookes Publishing.

Gleason, D. J. (1992). "Assessment of young children with visual and/or multiple handicaps", ICEVI Early Childhood Conference, 2-5 August 1992, Thailand.

Holte, L., Prickett, J. G., Van Dyke, D. C., Olson, R. J., Lubrica, P., Knutson, C. L., et al. (2006). "Issues in the evaluation of infants and young children who are suspected of or who are deaf-Blind", Infants and Young Children, 19 (3), 213- 227.

Iacono, T., Carter, M. \& Hook, J. (1998). "Identification of intentional communication in students with severe and multiple disabilities", Augmentative and Alternative Communication, 14 (2), 102114.

Janssen, M. J., Riksen-Walraven, J. M. \& Van Dijk, J. P. M. (2006). “Applying the diagnostic intervention model for fostering harmonious interactions between deaf-blind children and their educators: A case study", Journal of V isual Impairment \& Blindnes, 100 (2), 91-105.

Mahone, E.M. (2005). "Measurement of attention and related functions in the preschool child", Mental Retardation and Developmental Disabilities Research Reviews, 11, 216-225.

Mallineni, S., Nutheti, R., Thangadurai, S. \& Thangadurai, P. (2006). "Non-verbal communication in children with visual impairment", British Journal of Visual Impairment. 24, 30-33.

Mertens, D. M. \& McLaughlin, J. A. (1995). Research methods in special education, Applied Social Research Methods Series, Vol. 37, Sage Publications.

McLaughlin, K. \& Cascella, P. W. (2008). "Eliciting a distal gesture via dynamic assessment among students with modarete to severe intellectual disability", Communication Disorders Quarterly, 29 (2), 75- 81.

Mundy, P., Delgado, C., Block, J., Venezia, M., Hogan, A. \& Seibert, J. (2003). Early Social Communication Scales (ESCS), University of Miami, https://www.researchgate.net/ publication/228984460_Early_social_communication_scales_ESCS.

Mundy, P. \& Stella, J. (2000). "Joint attention, social orienting, and nonverbal communication in Autism", Autism spectrum disorders: A transactional developmental perspective, Edts., A. M. Wetherby, \& B. M. Prizant, Baltimore: Paul H. Brookes Publishing Co.

Narayan, J. \& Bruce, S.M. (2006)."Perceptions of teachers and parents on the cognitive functioning of children with severe mental disability and children with congenital deafblindness", International Journal of Rehabilitation Research, 29 (1), 138-146.

Ogletree, B., Wetherby, A. \& Westling, D. (1992). "Profile of the prelinguistic intentional communicative behaviors of children with profound mental retardation", American Journal on Mental Retardation, 97, 186-196.

Olsson, C. (2006). The kaleidoscope of communication: Different perspectives on communication involving children with severe multiple disabilities, Unpublished dissertation, Stockholm Institute of Education.

Patton, M. Q. (2002). Qualitative research \& evaluation methods, Third Edition, California: Sage Publications, Inc. 
Ayylldı, E., Akçin, N., \& Güven, Y. (2016). Development of Preverbal Communication Skills Scale for Children with Multiple Disabilities and Visual Impairment. Journal of Human Sciences, 13(2), 2668-2681. doi:10.14687/jhs.v13i2.3718

Rainey Perry, M. (2003). "Relating improvisational music therapy with severely and multiply disabled children to communication development", Journal of Music Therapy, 40 (3), 227-246.

Rowland, C. (1984). "Preverbal communication of blind infants and their mothers", Journal of Visual Impairment \& Blindness, 9, 297-302.

Rowland, C. \& Schweigert, P. (2005). "Enhancing the acquisition of functional language and communication", Educating students who have visual impairments and other disabilities, Edts., S. Sacks \& R. Silberman, Baltimore: Paul H. Brookes.

Rowland, C. \& Stremel-Campbell, K. (1987). "Share and share alike: Conventional gestures to emergent language for learners with sensory impairments", Innovative program design for individuals with dual sensory impairments, Edts., L. Goetz, D. Guess \& K. Stremel-Campbell, Baltimore: Paul Brookes Publishing.

Stillman, R.\& Battle, C. (1985). Callier-Azusa Scale: Scales for the Assessment of Communicative Abilities, Texas: Callier Center for Communication Disorders.

Thuppal, M. \& Sobsey, D. (2006). "Children with special health care needs", Educating children with multiple disabilities: A collabortive approach, Edts., F. P. Orelove, D. Sobsey ve R. K. Silberman, Fourth Edition, Baltimore: Paul Brookes Publishing.

Tomasello, M. (1995). "Joint attention as social cognition", Joint attention: Its origins and role in development, Edts., C. Moore \& P. J. Dunham, New Jersey: Lawrence Erlbaum, Hillsdale.

Topbaş, S. (2008). “Dil Gelişimini Destekleme”, Öz̧̨l eğitim, Edt. Süleyman Eripek, Eskişehir: A.Ü. Açıöŏretim Fakültesi Yayını.

Topbaş, S., Maviş, İ. \& Erbaş, D. (2003). "Intentional communicative behaviors of Turkish speaking children with normal and delayed language development", Child: Care, Health \& Development, 29 (5), 345-355.

Vlaskamp, C. \& Cuppen-Fonteine, H. (2007). Reliability of assessing the sensory perception of children with profound intellectual and multiple disabilities, Child: Care,Health \&Development, 33 (5), 547-551.

Warner, C. \& Wolf Nelson, N. (2004). "Assessment of communication, language, and speech: Questions of "What to do next?", Psychoeducational assessment of preschool children, Edt., B. A. Bracken, Third Edition, New Jersey: Lawrence Erlbaum Associates, Inc., Publishers.

Westling, D. L. \& Fox, L. (2004). Teaching students with severe disabilities, Third Edition, New Jersey: Merrill Prentice Hall.

Wilder, J. (2008). Proximal processes of children with profound multiple disabilities, Unpublished dissertation, Stockholm University.

Yıldırım, A. \& Şimşek, H. (2008). Sosyal bilimlerde nitel araștırma yöntemleri. 7. Baskı. Ankara: Seçkin Yayincilik. 